\title{
Students' Attitudes Towards Learning English Vocabulary Through Collaborative Group Work Versus Individual Work
}

\author{
Su-Fei $\operatorname{Lin}^{1}$ \\ ${ }^{1}$ Language Centre, Chia-Yi University, Taiwan \\ Correspondence: Su-Fei Lin, Language Centre, Chia-Yi University, Taiwan. E-mail: louiselin818@gmail.com
}

Received: April 16, 2019

Accepted: May 29, 2019 Online Published: July 12, 2019

doi:10.5539/jel.v8n4p93

URL: https://doi.org/10.5539/jel.v8n4p93

\begin{abstract}
This study investigated university students' attitudes towards learning English vocabulary through collaborative group work $(\mathrm{GW})$ versus individual work (IW) while performing vocabulary-focused tasks following reading comprehension. The second year, non-English major, Taiwanese students $(\mathrm{N}=44)$ worked either in mixed ability groups of 3-4 or alone. The same students were exposed to the two treatments: classroom intervention was conducted with alternating sessions (one-week IW, one-week GW) for 12 weeks with accompanying tests of vocabulary learning. Attitude questionnaires (44 students) were administered before the classroom intervention and again after, together with interviews (24 students). Results showed that students increased in favourable attitude to IW more than to GW over the study period, even though their actual vocabulary learning improved more with GW. Nevertheless, by the end they did report GW as less stressful than IW and as providing better support and enabling more efficient work on the tasks, with greater likelihood of correct information being obtained. The findings suggest that enhancing students' vocabulary learning through GW was valuable despite student perceptions of it not being unambiguously favourable, and the use of GW in university English classes needs to be encouraged, albeit with continuity of group membership over time.
\end{abstract}

Keywords: vocabulary learning, group work, individual work, zone of proximal development (ZDP), attitudes

\section{Introduction}

Learners' vocabulary development is closely related to their reading ability (Laufer, 1992; Rupley et al., 1999; Keashen, 2011; Nation, 2013). In order to read authentic general English texts, students minimally need to know 5,000 -word families, and additionally 800 -word families for reading academic texts at university level (Nation, 2013). This ensures knowledge of about $95 \%$ of the running words of such texts although $98 \%$ is required for comprehension unsupported by dictionary use, or the like (Laufer, 1989; Hu \& Nation, 2000; Laufer \& Ravenhorst-Kalovski; 2010 Schmitt, Jiang, \& Grabe, 2011). Reading is also itself a crucial source from which much of this vocabulary may be learned (Krashen, 2011; Nation, 2013). However, the time spent on vocabulary in class is often quite little.

In our context of English classes for Taiwanese technological university students studying a variety of majors through L1, as in many others worldwide, teachers may give L1 translations of the new words before teaching a reading text or have students check the electronic dictionary by themselves during the class. Vocabulary learning, however, is left to be done outside the class, in fact through individual work (IW).

Insufficiency of English vocabulary knowledge of university students is therefore widely reported not only in Taiwan (Huang, 2001), but also in other quite well developed EFL countries such as Thailand (Chipadee et al., 2013) and Saudi Arabia (Al-Masrai \& Milton, 2012). In today's globalized world, such countries recognize the importance of a graduate workforce with a sound basic proficiency in English for international communication needs in the future work in business or the public sector, even if most majors are still taught in L1 at university itself. Hence while several solutions are already being tried, such as starting to teach English earlier in state schools, and promoting learner strategies and autonomy for self-learning out of class, research on any other means to boost learners' vocabulary size is timely. Experts still see intensive classroom vocabulary practice as crucial (Nation, 2013), so the current study focuses on how to make that more effective. Collaborative group work $(\mathrm{GW})$ presented itself as a vocabulary practice mode neglected in our and other contexts, but supported by positive reports of its success for other skills (e.g., speaking: Tuan \& Neomy, 2007; reading: Wichadee, 2007; writing: Li \& Vandermensbrugghe, 2011). It is also consistent with social theories of learning such as that of 
Vygotsky (1978) where the 'more knowledgeable other' (MKO) in a group can help a learner in their 'zone of proximal development' (ZDP).

While some largely unpublished research has been conducted on GW in Taiwan (Chen, 2008; Li, 2011; Lo, 2012), and GW is used there in some areas of language teaching, it is not typically used or researched for vocabulary learning tasks after reading (Lin, 2009). Indeed, there are few studies anywhere which have empirically investigated vocabulary learning through collaborative GW which we used, in direct contrast to IW. Furthermore, students' attitudes towards the use of such GW in language learning have been neglected despite their importance in the learning process. As Taqi and Al-Nouh state (2014, p. 52): "Group work also depends on the attitude of the students". Greenop (2007, p. 361) also warns: "However, students may not prefer this method or view it as useful, which could lead to hostility and obstruction of the methodology."

The present study, therefore, contributes both to local and wider research concerns by implementing collaborative GW in vocabulary learning, in contrast with IW, and finding out not just whether it leads to greater learning success, but crucially also about students' attitudes to the two modes of learning, and how they changed over the period of an intervention.

\section{Literature Review}

\subsection{Attitudes to Collaborative Group Work in Vocabulary Learning}

Students with positive thoughts and feelings towards the target language tend to have higher language achievement than students with a negative attitude (Donato \& Antonek, 1996; Donato, Antonek, \& Tucker, 1994). Studies have also found a relationship of the attitudes to teachers (Noels et al., 1999; Noels, 2001a), and, relevant to us, to the tasks (Green, 1993), with the level of success in learning the target language.

The literature furthermore often suggests that students have positive attitudes to Littlewood (2001), for example, surveyed 2,656 students from eleven different countries, eight in Asia (Taiwan was not included) and three in Europe. He found that most students in all countries question the traditional authority-based type of classroom. They liked to engage actively in the learning process and had a positive attitude towards working co-operatively in groups to achieve common goals. If $\mathrm{GW}$ is, as many experts believe or have found, also more effective for language learning (e.g., Gomleksize, 2007), and indeed improves attitudes to language learning in general (Ibnian, 2012), then this attitude is highly desirable.

An analysis of the literature further yields at least three beneficial ways in which it is suggested that tasks performed through GW might be associated with more favourable attitudes of learners than those performed through IW.

\subsubsection{Group Work Is Perceived to Be Beneficial Because It Increases the Opportunities for Language Learning}

It is expected that learners will see GW as a superior learning environment to IW because it affords more knowledge sources than IW, where the learner alone is their main source of information to perform a task. In both modes, of course, the teacher, textbook or (in some circumstances) computer may also be available. Storch (2005) compared the effectiveness of IW versus collaborative pair work when students produced a written text and confirmed, from interview data, that most students showed a positive attitude towards GW because it provided learners with more opportunities to observe, learn form each other, and receive feedback.

In Taiwan, Lin, Chan and Hsiao (2011) investigated 91 secondary school students' perceptions of learning English vocabulary collaboratively with computers. Students, over three weeks, were assigned randomly to learn individually without computers, or collaboratively (4-5 students in a group) without computers, or collaboratively with computers.

Although those working individually scored better for learning success, at least in the immediate post-tests (scores of immediate and delayed post-test for all three groups: individual learning without computers: $\mathrm{M}=$ 40.30, $\mathrm{M}=25.19$; collaborative learning without computers: $\mathrm{M}=35.50, \mathrm{M}=22.96$; collaborative learning with computers $\mathrm{M}=35.68, \mathrm{M}=25.44$ ), the attitude data still showed that over $60 \%$ of students in the collaborative computer group were aware of the importance of the collaboration, and had a positive attitude to learning in groups, giving as reason that they had opportunities to discuss and work together with others to complete a task. They further agreed that learning in groups with the use of computer helped them learn more efficiently than in IW. The students who worked individually or worked collaboratively without the use of computer, tended to pay less attention to the learning activity, however.

McDonough (2004), by contrast, investigated sixteen intermediate-level university students' perceptions, improvement in using the target forms over eight weeks, and occurrence of learning opportunities, in pair and 
small group activities in Thailand. Learners completed 10-15-minute information-gap and opinion-exchange tasks using conditional clauses to talk about environmental problems, through pair or small group work. The test results showed that both high-participation and low-participation learners increased their production of the conditional clauses correctly, but students tended to give negative attitude responses to the usefulness of GW regardless of their level of improvement. In addition, students' attitudes varied about whether talking to their classmates helped them learn English. The reasons reported included: GW was useful for having your work corrected by friends (5/16 learners), for practising oral skills (4/16 learners), for learning vocabulary and grammar (4/16 learners), and not helpful at all (3/16 learners) because they received incorrect help (incorrect grammar information) from their fellow students or because the other group members knew little English.

Thus, we see that attitudes to the benefits of the wider range of knowledge sources available in GW than IW are, in fact, not always recognized by students, and indeed are not always reflected in actual learning success.

\subsubsection{Group Work Is Felt to Promote Motivation for Language Learning}

The influence of motivation on vocabulary learning has been identified by many studies (Gardner, Lalonde, \& Moorcroft, 1985; Gardner \& MacIntyre, 1991; Tseng \& Schmitte, 2008; Soureshjani \& Naseri, 2011; Fontecha \& Gallego, 2012; Zheng, 2012). Both intrinsic and extrinsic motivation (Deci \& Ryan, 1985) play a significant role in vocabulary learning and, in both ways, GW is often seen as enhancing motivation more than IW.

Learners often simply report GW as more interesting (e.g., Lin et al., 2011), and such intrinsic motivation may be expected to drive them to work harder and learn more. Moreover, weaker learners in IW might consider that achieving the pre-set criteria was not possible with their limited knowledge, so they might put in little effort or stop doing the task (Johnson \& Johnson, 1994). In GW, however, they may see the task as more achievable and so engage more. Furthermore, they may feel obliged not to appear lazy in front of the other members of the group (extrinsic motivation: peer pressure) and so may work harder (greater motivational intensity) than IW, rather than becoming unmotivated 'free riders'.

In group work, every little effort student makes benefits the team, even the contribution is small (Glasser, 1986). This helps students, especially low-achieving students, build up their self-confidence, because helping others in completing their tasks may serve to "enhance individual students' own sense of self-efficacy and self-worth" (Cooper et al., 1990, p. 15). When they work alone, however, a little effort receives no credit, so does not add to motivation. As Zhang reports from one Chinese student studying via GW in Finland: "I have the initiative to fully engage in active thinking and brainstorming. I enjoy this activity a lot because I am able to perform the leading role during learning process" (2015, p. 42).

In addition, when high-achieving students explain things to low-achieving students, they not only benefit from re-thinking and clarifying the important points of the problems that they do/do not understand (Cooper, 1999) which may enhance the high-achiever's feeling of fulfillment and so their motivation. Furthermore, receiving explanations helps low-achieving students learn by correcting their misconceptions about the problems or by connecting new information with the knowledge they learned previously, etc. Being able to overcome difficulties in the task may increase low-achieving students' feelings of success and so increase their motivation for learning vocabulary.

Thus, the literature strongly supports the value of GW for motivating students in a variety of ways, which, in turn, should lead to better learning. Evidence for these detailed effects from actual student attitude data, however, remains sparse, and it is part of current study's purpose to fill this gap.

\subsubsection{Group Work Is Seen as Promoting a Less Stressful Learning Environment}

Feeling anxious influence the quality of performance and affects the amount of effort learners invest in the task. Krashen (1988) points out that the "affective filter" (which includes aspects of anxiety/stress and self-confidence) is like a mental barrier that can limit students' ability to learn. It does not affect students' language acquisition directly, but prevents input from reaching the language acquisition part of the brain. Studies have indeed shown that the rate of vocabulary learning is slower for students who report experiencing language anxiety (MacIntyre \& Gardner, 1989, 1994).

In IW, students are asked to work on the task by themselves without interacting with classmates. Hence, frustration and anxiety may be generated, for example, when the pre-set criteria for success are considered to be important, but the students are not able to meet them because of the limits of their English ability (Bailey et al., 2000). Collaborative GW, however, provides a friendly, non-threatening and supportive environment for the students, so they should have more confidence to express their own opinions, exchange information, give suggestions, and receive assistance. Instead of competing with the classmate sitting nearby, as in IW, it is more 
likely that students will be helping their fellow group members to achieve the group goal and may even find this fun (Storch, 2005). As GÖmleksiz (2007) found engineering students studying in Turkey like the supportive and comfortable learning environment in GW more than that of in teacher-centered classroom context. This also led to a positive impact on their improvement in vocabulary knowledge and learning active-passive in English.

Anxiety, apprehension and stress are related to self-esteem. In IW, learners' self-esteem is based on their own perceived ability to achieve the pre-set criteria or not, often based on past success. The learners are expected to take responsibility for assessing their own progress and quality of effort in achieving the learning goals successfully. However, learners may encounter difficulties in doing the task and feel too embarrassed to ask for assistance from the teacher, perhaps because the questions they have are too simple. In short, their self-esteem would be affected by this; they might 'lose face'. In GW, however, students may feel more comfortable with help from classmates because their self-esteem (or 'face') may feel less threatened. For example, when a learner cannot express the points of a question clearly to the teacher, their group members can help; similarly, their fellow group members can help them answer simple questions about things they do not know. Moreover, this is all expected to reduce learner anxiety while the task is completed.

Thus, again we see many reasons why learners may prefer GW due to issues of self-esteem connected with stress/anxiety, which, in turn, impact on motivation and so on learning itself. Nevertheless, there exist dissenting views, such as that for Chinese students interacting in groups may be stressful for cultural reasons (Zhang, 2015; Hui, 2005). Once again there is a dearth of research directly on what student attitudes reveal on this issue.

\section{Research Aims}

Although most of the literature suggests more positive learner attitudes to GW than to IW, and this is backed by much theoretical support, we saw above that not all empirical studies did find clear learner support for GW over IW. This study therefore aims to further investigate students' attitudes towards vocabulary learning through IW versus through GW in a new context: post-reading English vocabulary learning in a Taiwan university.

Since GW for this sort of task was not familiar in the context, but was implemented especially for the study, we may also expect to see some changes in attitude, especially to GW, over the period of the study. Attitudes are not seen as innate, but as learned, (Fishbein \& Ajzen, 1975), developed and "organized through experience" (Fishbein, 1967, p. 21). Therefore, attitudes rarely stay static, but change over time during a learning process (Baker, 1992).

\section{Method}

\subsection{Participants}

The participants were 44, second year, non-English major students from various departments and attended the required English reading course for improving their basic general English reading ability and vocabulary size. There were 28 male and 16 female students, aged from 18 to 20, with pre-intermediate English level as measured with the national test, GEPT by the Applied English Department. All spoke Chinese as their first language and had learned English through the normal state education system in Taiwan, supplemented by attending cram schools. They took courses in their majors through the medium of Chinese.

\subsection{Procedure}

All 44 participants took a pre-test of knowledge of the vocabulary in the practice tasks carried out these tasks in IW and GW over 12 weeks, took immediate post-tests, and a delayed post-test (for test details see Lin, 2013). The focus of the present study is more on students' questionnaire responses before the start and after the end of the classroom intervention, and interviews with some students after. For GW activities, all 44 students were arranged into groups of 3 students, with high, mid- and low prior knowledge of the target words (Donato, 1994; Ohta, 2000). For IW, the same 44 target participants worked individually on the same kind of tasks in class, in alternate weeks.

In each lesson, first a reading text was introduced from the course textbook Day and Yamanaka (2007). After the schemata activating activities, the teacher explained the general meaning of the reading text, and key vocabulary, and suggested a reading comprehension strategy to the students. Students then individually read the text, and completed the reading comprehension exercise provided in the textbook. Following that, the teacher introduced and explained in English and Mandarin the textbook vocabulary exercises. Students did these for 15-20 minutes either in IW or GW mode in alternating sessions (one-week IW, one-week GW).

\subsection{The Collaborative Group Work}

1) There were three students with different levels of vocabulary knowledge in each group (Donato, 1994; Ohta, 
2000). The students were not necessarily in the same group every time; they had to switch to another group when any two group members had the same level of vocabulary knowledge of the target words in the task (as determined by the pre-test). That was so the group always consisted of students with different levels of vocabulary knowledge.

2) The students sat at desks moved so as to touch each other in a line.

3) The students were encouraged to talk in English. They could use Mandarin Chinese when necessary. Using exploratory talk during group discussion was emphasized (and they had 2 classes, 100 minutes, training session on this beforehand).

4) The students in the groups had total responsibility for completing the vocabulary task successfully. For example, they could choose to work on everything together or to divide the vocabulary task into specific tasks for each group member, e.g. deciding that each person did two questions or that student $\mathrm{A}$ found out the synonyms of the vocabulary, student B looked for the antonyms, etc.; they could choose (or not) a member to be their leader to monitor the progress of the group and keep the discussion going by encouraging the contribution of other group members; they could decide to ask the teacher for help when they had difficulty answering the questions, or they could decide themselves if the answers they came up with were correct or not.

5) The teacher worked as a facilitator during the group work activities: for example, she might help students with their vocabulary tasks when they required it, and might facilitate exploratory conversations by going round each group, encouraging students to exchange knowledge about vocabulary, and asking them to give constructive reasons for their suggestions, and to listen to each other carefully, etc.

6) The use of a dictionary was allowed.

7) The group work took about $15-20$ minutes. The answers to the vocabulary exercises were given after the immediate post-test.

\subsection{The Individual Work}

1) All the students did the vocabulary task provided in the textbook individually, seated at separated desks.

2) Students were encouraged to work on their own without interacting with classmates. The teacher gave assistance to the students only when they asked. (Some interaction with peers was allowed, because it was normal practice during individual work in classes; it was usual for teachers to allow this and for students to want to do it.)

3) The students had about 15-20 minutes and could check the target words with the paper dictionary or electronic dictionary as they wished. The answers to the vocabulary exercises were given after the immediate post-test.

\subsection{Research Instruments Eliciting Attitudes}

\subsubsection{Questionnaires}

The pre-questionnaire written in Chinese was divided into two parts. The first part covered students' personal information. The second part of the questionnaire contained 18 questions designed to find out students' initial attitude towards working on vocabulary tasks in IW or in GW. The format of the 18 questions was a five-point scale (Likert scale: $4=\mathrm{a}$ lot, $3=$ moderately, $2=$ somewhat, $1=$ a little, $0=$ not at all) (Rasinger, 2008). The post-questionnaire contained 18 questions, parallel with those of part $\mathrm{B}$ in the pre-questionnaire, but reworded to refer to what the students had done rather than what they were about to do. Nine of the questions referred to IW and nine to GW, with each set of nine items made up of subsets of three items, each of which corresponded to one of the three areas distinguished in the literature review (Table 1 and Appendix 2).

\subsubsection{Interviews}

Semi-structured interviews with 24 participants were conducted in Chinese after the intervention had finished but before the post-questionnaires had been completed. The interview questions related to students' attitudes towards vocabulary learning with $\mathrm{GW}(\mathrm{N}=6)$ and IW $(\mathrm{N}=6)$, and what they perceive to be the function of $\mathrm{GW}$ $(\mathrm{N}=6)$ and IW $(\mathrm{N}=6)$.

\subsection{Data Analysis}

Questionnaire data were entered into SPSS (Version 16) and analyzed using descriptive statistics, and ANOVA tests. The interview data was fully transcribed translated into English, and analyzed with the procedure for coding, categorization, description and interpretation suggested by and Patton (2002); Bogdan and Biklen (2007). 


\section{Result and Discussion}

As indicated earlier, we are interested to detect both differences in attitude to IW and GW, and any changes in that over the period of the intervention. We divide the account in parallel with the three key attitude areas highlighted in the literature review.

\subsection{Perceived Success/Correctness/Efficiency in Learning Vocabulary Through IW or GW over the Period of Study}

Generally speaking, the students held moderately positive attitudes towards learning vocabulary successfully through both IW and GW, a little above the midpoint 2 on the scale. The interaction effect alone was significant $(\mathrm{F}=4.137, \mathrm{p}=.048)$, reflecting the fact that students initially imagined learning vocabulary through GW (MGW $=2.32$ ) would be more successful than learning vocabulary through IW (MIW $=2.07$ ), but their attitudes changed after the GW was implemented. The students then reported that learning vocabulary through IW (MIW $=2.48)$ was more successful than through GW $(M G W=2.20)$. Indeed, while their belief in success with IW improved somewhat (.41) after the researcher implementation of it, that in success with GW, in fact, fell (by .12).

This was, in fact, in direct conflict with what was found (Lin, 2018) in the actual vocabulary learning results, and to some extent the interview data on what helped vocabulary learning. The results of the tests of vocabulary knowledge showed that students' overall improvement with both IW and GW seemed to yield similar pre-post improvement scores at the end of the intervention (IW pre-post difference mean scores rose from $11.71 \%$ to $51.96 \%$, GW rose from $29.77 \%$ to $50.07 \%$ ); final session post-test scores with GW were much higher than those with IW however (GW 71.48\%, IW 64.46\%). Vocabulary scores from the overall delayed post-test for GW were also significantly higher than those for IW, although only by a small margin (MGW $=38 \%$, MIW $=36 \%$ ). In fact, our findings agreed with McDonough's (2004) investigation, which showed that students involved in pair and small group activities had better improvement in producing the target forms, even though they did not think that pair and small group activities were useful for language learning.

From interview data, students reported discovering richer lexical information in GW than in IW. This seemed to be because they had more stimulation to notice new aspects of words, and more opportunities to retrieve words and add to word knowledge from other group members during group discussions; they also had the chance to learn more pieces of word knowledge by giving help (e.g., explaining things) to their fellow group members. For example, [8B-S] showed more active engagement with the information when he said: "The antonym of break down is operating according to my dictionary. Group members found out that working can also be the antonym of break down. The word, working is even easier than operating. I never thought that working can be the antonym of break down, but the group members do. So, I use the word working as the antonym of break down." The processes of GW were reported as providing richer support for retention than IW, both in terms of multiple retrievals and generative use, in Nation's terms (2013), and through their interactive nature. As [8B-S] said: "I can remember better about the phrases or words that are discussed in the group discussion. For example, the phrase 'pay off' in the sentence: Sandy took out many loans for medical school, so it will take them a long time to pay off his debts. Besides, group members often tell me better examples to help me understand about it."

The unexpected attitude findings from the questionnaire may have resulted from the difficulties students encountered during GW activities. Since students worked with different group members in almost every GW activity, some students might have hesitated to interact with unfamiliar group members which reduced the opportunities for gaining learning benefits from them in GW. For example, [7A-S] said "When I work with the groupmates who I am familiar with, I can relax a little bit and depend on them more. If I work with the groupmates who I know very little about, I will have to work harder on the task by myself".

This could have decreased, or at least made subjectively more challenging, the opportunities for students acting as sources for each other, for example, high-achieving students giving word information, low-achieving students receiving suggestions or corrections. Furthermore, being hesitant to talk to unfamiliar group members might be enhanced by the local cultural impact of Confucian social value, by which being careful about what a person says is considered as moral goodness of character and behaviour while being outspoken appears to be immodest (Ho et al., 2001).

Regarding the perceived efficiency of working in each activity over the period of the study, students did not initially report strong positive attitudes towards working efficiently on the vocabulary tasks through IW (MIW = 1.89 , MGW $=2.39$ ). Means for both types of activity were, however, higher after the implementation of the activities than before (MIW $=2.25, \mathrm{MGW}=2.45$ ). From ANOVA tests of within-subjects effects, this overall pre-post effect was significant $(\mathrm{F}=4.261, \mathrm{p}=.045)$. Although this increase was descriptively greater for IW $(.36)$ than for GW (.06) the interaction effect was not significant, however. Furthermore, the difference of mean rating 
between GW and IW before the classroom intervention was higher $(=0.540)$ than the difference of mean rating between GW and IW after the classroom intervention $(=0.20)$. The students thought that working in GW was descriptively much more efficient than working in IW before the classroom intervention. After GW was implemented, however, their attitudes slightly changed. The students still reported that working in GW was more efficient, so the overall effect for difference between activities was significant $(F=7.504, p=.009)$, but by a narrower margin. This matches my expectation that students would perceive GW as more efficient than IW, though it was surprising that the difference between the two narrowed rather than widened after experiencing the activities.

Regarding the perception of obtaining correct vocabulary information, initially the students did not seem to show very positive attitudes towards obtaining correct information in IW (MIW $=1.89, \mathrm{MGW}=2.27)$ Means for both types of activity were, however, higher after the implementation of the activities than before (MIW $=2.25$, MGW = 2.32), and from ANOVA tests of within-subjects effects, the overall pre-post effect was nearly significant $(\mathrm{F}=4.027, \mathrm{p}=.051)$. Although the perceived increase in correct information obtained was greater for IW (.36) than for GW (.05), the interaction effect was not significant, however. Furthermore, the difference of mean rating between GW and IW before the classroom intervention was greater $(=0.28)$ than the difference of mean rating between GW and IW after the classroom intervention (0.07), and the overall difference between activities was significant $(\mathrm{F}=6.869, \mathrm{p}=.012)$. This shows that the students initially thought that they would obtain substantially much more correct vocabulary information through GW than through IW. However, their attitudes changed slightly after the GW activity was implemented. The students still reported that GW gave more correct information than IW but the difference in correct vocabulary information they obtained through GW versus IW was not as great as they expected (only 0.07). Again, this was in line with my expectation (Ohta, 2000, 2001; Swain \& Lapkin, 1998) that students should see GW as a better source of correct information than IW. However, it was again not expected that the effect of experiencing the activities would reduce their perception of the size of the advantage of GW over IW.

\subsection{Perceived Motivation/Concentration/Liking in Learning Vocabulary Through Each Activity over the Period of Study}

Regarding reported motivation, students did not report being strongly motivated initially to learn vocabulary through IW (M IW = 1.82, MGW = 2.11). Means for both types of activity considered together were significantly higher after the implementation of the activities than before $(F=4.137, p=.048)$. However, the interaction effect was also significant $(\mathrm{F}=7.308, \mathrm{p}=.010)$ : the overall improvement in attitude was due predominantly to the increase for IW (.5) not GW (.03). Furthermore, students generally agreed that they would be more motivated to learn vocabulary when working in GW (Mean $=2.11$ ) than in IW (Mean $=1.82$ ) before the classroom intervention. However, their attitudes changed after the GW was implemented. The students tended then to report that they were much more motivated to learn vocabulary when working in IW (Mean $=2.32)$ than in GW (Mean $=2.14)$.

The reason for this unexpected result with hindsight is perhaps that, as mentioned above, working with different group members in nearly every GW activity hindered the development of the motivational features mentioned in the literature, since students needed more time and experience working together with the same group members to develop a certain level of familiarity before they were able to work cooperatively in groups and develop effective group function (Fox \& Lorge, 1962). Glasser (1986) for example suggested several reasons why learning teams succeeded in motivating students to learn, but began with the assertion that students gained a sense of belonging by working in a team of two to five. These reasons included the development of group functions (e.g., dividing tasks, assigning group roles) and communication among group members (e.g., encouraging group members to contribute despite feelings of uneasiness).

Regarding the perceived concentration, the students did not seem to feel that they could concentrate particularly well on vocabulary tasks in IW beforehand ( $\mathrm{MIW}=1.82, \mathrm{MGW}=2.25$ in pre-questionnaire; $\mathrm{MIW}=2.55$, $\mathrm{MGW}=2.39$ in post-questionnaire). The means for both types of activity together were however significantly higher after the implementation of the activities than before $(\mathrm{F}=16.747, \mathrm{p}<.001)$. The students felt their concentration level for learning vocabulary through both activities improved, although not to a very high level. However, the interaction effect was also significant $(F=6.582, p=.014)$. Students generally agreed that their concentration level for vocabulary learning in GW would be better than that for IW before the classroom intervention (by .41). However, after the GW was implemented the students tended then to report that they concentrated better in IW than in GW (by .16). Students' perceived concentration with IW, in fact, improved pre-post by .71 while that with GW improved by only .14 . 
Once again, this was unexpected in the light of the actual changes in vocabulary knowledge (as mentioned previously) but was consistent with some findings from the interviews. GW was very likely to produce a high level of noise inside the group, for example, during group discussion while finding out the synonym of a word, or discussing the questions group members raised as reported by students. The student [10B-S] said, "When we work in groups, all the group members work on the same question together; for example, finding out the synonym of a word, and discussing the questions group members raise. So, I am not able to think about questions quietly by myself when working in groups". This affected students' concentration in GW as they were distracted and not able to complete the tasks or memorize words in a quiet environment.

Regarding perceived liking for each activity, students initially reported moderately positive attitudes towards learning vocabulary through both modes $(\mathrm{MIW}=2.16, \mathrm{MGW}=2.32)$. Means for both types of activity were higher after the implementation of the activities than before (MIW $=2.61, \mathrm{MGW}=2.45)$. From ANOVA tests of within-subjects effects, this overall effect was significant $(F=5.87, p=.020)$. Though liking for IW increased by a little more (.45) than the liking for GW (.13), the interaction effect was not significant. Furthermore, students generally agreed that they would like learning vocabulary through $\mathrm{GW}(\mathrm{MGW}=2.32)$ more than learning vocabulary through IW $(\mathrm{MIW}=2.16)$ before the classroom intervention. However, their attitudes changed after the GW was implemented. The students tended then to report that they liked IW (MIW $=2.61$ ) more than GW $(\mathrm{MGW}=2.45)$, though as I said, the interaction effect was not significant.

The results were consistent with the finding of Littlewood (2001) that 2656 students from eleven different countries reported liking working in groups to achieve the common goals and actively engaging in the learning process. However, Littlewood did not compare GW with IW, nor investigate the relationship between attitude and any form of success/achievement as I did. The students' liking for the less familiar learning method, GW rose, even though not to a very high level. Such an effect has been commonly found in educational research where the teacher intervened with some new teaching. However, it persisted even after 12 weeks of intervention, suggesting that it was not just the effect of novelty that produced it. The fact that students' liking for GW rose only slightly and was outstripped by their liking for IW might reflect a number of possible factors. Familiarity of task, time, and effort were factors mentioned in the interview affecting liking etc. Students liking for GW also have been limited, because of the unfamiliarity of group members, or because they found that they were obliged to contribute more when working in groups as opposed to working individually. It was also possible that students' limited liking for GW was connected with their (mistaken) belief that GW was a less successful method of learning vocabulary.

\subsection{Perceived Stress/Confidence/Support in Learning Vocabulary Through Each Activity over the Period of Study}

The students initially perceived that they would experience some degree of stress while working in both IW and $\mathrm{GW}$ activities $(\mathrm{MIW}=2.32, \mathrm{MGW}=2.23$. This, however, fell by the end of the intervention, descriptively more so for GW where it ended up in the 'not stressful' lower half of the response scale as we anticipated (MIW = $2.05, \mathrm{MGW}=1.86)$. This overall decrease over time was significant $(\mathrm{F}=4.349, \mathrm{p}=.043)$. Although the decrease in stress was slightly greater for GW (.37) than for IW (.27), the interaction effect was not significant however.

Students furthermore generally agreed that they would have more stress in IW both before and after the classroom intervention, though this difference was not significant. Their attitudes in that respect stayed relatively the same after the GW was implemented. It was reassuring that the teacher's implementation of the activities would, in fact, lead to students reporting being less stressed about performing them, especially the less familiar GW activity. In the interview data, [11A-S] said "I can remember more vocabulary information when I work in groups. It provides us a friendly environment when group members work on the task together". [12A-S] said "I prefer to work in groups......I can learn in a more relaxed environment, for example, chatting a little bit during group work."

Regarding confidence in learning vocabulary through each activity, the students did not seem to initially feel great confidence in IW activities, but showed positive confidence in GW (Mean, IW = 1.80, GW = 2.16). Ratings, however, were higher only for IW after the implementation of the activities than before (IW $=2.27$, GW $=2.16)$. This interaction effect was significant $(\mathrm{F}=4.268, \mathrm{p}=.045)$ reflecting the fact that while the mean for IW was higher (by .47) after the implementation, the mean for GW (2.16), in fact, stayed the same. The students tended afterwards to report that they had more confidence in learning vocabulary through IW than through GW (difference, 11).

This unexpected result is possibly due to the discussion in GW being affected because students seemed to feel unease interacting with unfamiliar group members. [9A-S] reported "I am a shy person. So, I don't usually talk much. Talking to someone I am familiar with is easier for me." In other words, the opportunities for them to 
build up their self-confidence in GW were reduced compared with what our literature review suggested. Moreover, working with high-achieving students seemed to unexpectedly generate a certain level of pressure on low-achieving students. Low-achieving students might lack confidence to give suggestions or corrections to group members since they considered themselves inferior to high-achieving students in GW. [4A-S, low-achieving student] said: "I didn't really give corrections to group members because I don't know how to explain or prove what I say is correct if he[/she] insists on his own answers." Kowal and Swain (1994) suggested that students' collaboration in groups might be reduced when their language proficiency level had a large difference and this might explain our result here.

Regarding the degree of claimed support, which we argue is also anxiety related, the students initially indeed did not seem to think that they would be very well-supported while working in IW activities, but slightly more so in GW $(\mathrm{MIW}=1.82, \mathrm{MGW}=2.14)$. Means for both types of activity were higher after the implementation of the activities than before $(\mathrm{MIW}=2.39, \mathrm{MGW}=2.34)$. This overall effect was significant $(\mathrm{F}=9.094, \mathrm{p}=.004)$ : the attitude of the students towards the degree of support they received in IW and GW activities definitely increased after the teacher's intervention. The interaction effect was not significant, however, although the increase in favourable attitude was again greater for IW (.57) than for GW (.29). Nevertheless, students overall agreed that they would receive more support in GW than in IW both before and after the implementation of the activities (though this difference was not quite significant). This was more in line with what I expected, since one of the key features of $\mathrm{GW}$ was suppose to be that it afforded more kinds of support, from group members, than working alone. [12A-S] said: "I prefer to work in groups.... I can learn in a more relaxed environment, for example, chatting a little bit during group work".

\section{Conclusion}

As summarised in Table 1, only on four out of nine attitudes did students, in fact, prefer GW over IW at the end of the intervention, even descriptively, in accordance with what we expected from most of the literature. Furthermore, only one attitude to GW changed to become more favourable to a greater extent than attitude to IW did, suggesting that the experience of the intervention had more of an impact on students' feelings about their familiar mode of working, IW, than the relatively new mode, GW. That is remarkable given that 'novelty effect' in research usual favours the less familiar treatment.

Table 1. Descriptive summary of findings for attitudes in the questionnaire

\begin{tabular}{llll}
\hline Attitude area: & Perception of: & $\begin{array}{l}\text { Attitude to GW is higher/lower than attitude } \\
\text { to IW as expected, after intervention? }\end{array}$ & $\begin{array}{l}\text { Intervention changed attitude to GW } \\
\text { more than attitude to IW? }\end{array}$ \\
\hline Learning & successfulness & $\mathrm{n}$ & $\mathrm{n}$ \\
& efficiency & $\mathrm{y}$ & $\mathrm{n}$ \\
\multirow{3}{*}{ Motivation } & correctness & $\mathrm{y}$ & $\mathrm{n}$ \\
& effort & $\mathrm{n}$ & $\mathrm{n}$ \\
& concentration & $\mathrm{n}$ & $\mathrm{n}$ \\
\multirow{3}{*}{ Stress/Anxiety } & liking & $\mathrm{n}$ & $\mathrm{n}$ \\
& lack of stress & $\mathrm{y}$ & $\mathrm{y}$ \\
& confidence & $\mathrm{n}$ & $\mathrm{n}$ \\
& support & $\mathrm{y}$ & $\mathrm{n}$ \\
\hline
\end{tabular}

The main reason we suggested for this initially counter-intuitive finding was a particular choice we made in the design of the intervention. Clearly any implementation of GW versus IW involves a large number of decisions. These two modes of working are not monolithic choices but contain with them a number of more specific choices that have to be made about many things. Many of these task variables are uncontrolled, or even unreported, in studies in the literature, and their effects are therefore not fully understood.

One such choice which we made concerned the precise composition of the groups. While the literature (Watanabe, 2008) often suggests that mixed ability groups are beneficial in GW, primarily so as to make sure that learning opportunities arise, there are of course several ways of implementing this idea. The one which we adopted (Watanabe, 2008) was precisely calibrated to the individual vocabulary task. If we had followed the practice of much cooperative GW (Johnson \& Johnson, 1994) where groups contained members with a range of general English proficiencies, it might still have occurred that the vocabulary of a specific task was not familiar to any of them or was largely familiar to all of them. Hence, we spent a great deal of time and effort ensuring that the group always consisted of students with different levels of vocabulary knowledge relative to the specific 
task of each lesson. Thus, they differed not so much in general proficiency as in task-specific prio vocabulary knowledge. This, however, had the effect of loss of continuity of group membership: students were meeting different other group members in almost every GW task. In addition, the intervention was implemented near the start of a course where students were brought together from a variety of different majors who did not know each other well before arriving at the course. Furthermore, the GW differed from GW that students were familiar with in other kinds of class, where group members were chosen by students.

On the other hand, it could be argue that the IW was also not as familiar as we imagined (Lin, 2018), given that in our study it was always followed by an immediate test, which did not usually happen but was required for the research, so as to be able to measure the learning that occurred. Possibly this innovation, although common to both treatments, appeared to students to be actually more novel and effective in a number of ways than the IW/GW difference which was our focus of attention.

All the above impacted not only on perceived successfulness of learning but also on the three motivational attitudes measured, and reported confidence. Indeed, working with unfamiliar group members in each GW activity seemed to be the main factor that affected students' attitude towards GW. Due to unfamiliarity with members in group, students might not have helped or encouraged others as much as might have expected, which is an important elements of group construction in motivating student' learning in GW (Glasser, 1986). Students probably needed more time and experience working together with the same group members to develop a certain level of familiarity before they were able to work cooperatively in groups fully effectively (Fox \& Lorge, 1962). The best policy for group formation might be to have students with mixed abilities work in the same group until the course finished instead of changing group members everytime they do group work.

Despite the above findings, as we noted, GW did better than IW in promoting actual vocabulary learning. Hence, we may conclude that a method can benefit learning even in the face of some attitudes that do not specially favour it. Possibly, confidence in success, liking, and perceived motivation are not actually essential for learning. By contrast, it seems that lowered stress, support, and perceived accuracy of information are more associated with objectively measured learning improvement. This was in line with Storch's (2005) study, which showed that GW provided learners with a more supportive and lower-anxiety environment than IW, which helped learners to recall the vocabulary they needed, and mostly they already knew, in completing writing tasks. Moreover, having more opportunity to receive word knowledge from group members and learn more pieces of word knowledge by giving help (e.g., explaining things) to their fellow group members may be the factors affecting students' perceived efficiency and correctness of vocabulary information (Lin, 2018).

\section{Pedagogical and Research Implication}

For pedagogical implementation of GW in our context, and other similar ones, there seems to be one key implication. Despite exhortation from the literature that GW works better in groups with different abilities, which often may not be the case where self-selected group membership is allowed, it appears that this should not over-ride the maintenance of continuity of group membership. While the Vygotskian requirement for an MKO is clearly important for social learning, it is not so often suggested that attitudes to such learning are also important and need to be facilitated by the affective lubrication which stems from familiarity among members of the groups. Although in our study GW performed better than IW in terms of actual learning despite the lack of this element, even better results might have been obtained with more favourable GW attitude development founded on stronger group familiarity and identity. The best policy for group formation might therefore be to have students with mixed relevant abilities (in our case, overall vocabulary proficiencies or sizes), established at the start, work in the same group until the course finished instead of changing group members every time they do $\mathrm{GW}$ in accordance with their task specific prior knowledge.

The slight problem with concentration could be overcome by reminding students to speak softly during group discussion before the GW started. Students could be encouraged to arrange some time after group discussion for reviewing or memorizing vocabulary together or individually if necessary. Moreover, off-task chatting during GW or during the time between after group discussion and before the immediate post-test was the other factor that affected students' perceived level of concentration in GW. This problem can be dealt with by arranging activities such as reporting group discussion results to all classmates after GW to reduce unnecessary chatting.

As far as research is concerned, clearly there needs to be more work on the effects of familiarity with each other of group members and of different ways of mixing abilities. Furthermore, this study mainly examined the student dimension of learning vocabulary through GW. However, the interaction between the teacher and the students could also influence students' vocabulary learning. Further research might want to examine to what extent the teacher factor influenced students' vocabulary learning in GW and IW, and the attitude of teachers towards 
facilitating students' vocabulary learning in group work.

\section{References}

Al-Masrai, A., \& Milton, J. (2012). The vocabulary knowledge of university students in Saudi Arabia. Perspectives (TESOL Arabia), 19(3), 13-20.

Bailey, P., Onwuegbuzie, A. J., \& Daley, C. E. (2000). Correlates of anxiety at three stages of the foreign language learning process. Journal of Language and Social Psychology, 19(4), 474-490. https://doi.org/10.1177/0261927X00019004005

Baker. (1992). Attitudes and language. England: Multilingual Matters.

Bogdan, R. C., \& Biklen, S. K. (2007). Qualitative research for education: An introduction to theory and methods (5th ed.). Boston: Allyn \& Bacon.

Chen, F. H. (2008). A study of cooperative learning in the college speaking classroom. Unpublished M.A. dissertation, Chaoyang University of Technology, Taiwan.

Chinpakdee, M., Nomnian, S., \& Suraratdecha, S. (2013). English vocabulary knowledge and vocabulary learning strategies of Thai undergraduate students in science program. Sukhothai Thammathirat Open University, Thailand: 3rd STOU Graduate Research Conference.

Cooper, J. et al. (1990). Cooperative learning and college instruction: effective use of student learning teams. ERIC Document Reproduction Service No. ED 348920.

Cooper, M. A. (1999). Classroom choices from a cognitive perspective on peer learning. In A. M. O’Donnell \& A. King (Eds.), Cognitive perspectives on peer learning (pp. 215-234). Hillsdale, NJ: Lawrence Erlbaum Associates.

Day, R. R., \& Yamanaka, J. (2007). 1 Cover to Cover. Oxford University Press.

Deci, E. L., \& Ryan, R. M. (1985). Intrinsic motivation and self-determination in human behaviour. New York: Plenum. https://doi.org/10.1007/978-1-4899-2271-7

Donato, R. (1994). Collective scaffolding in second language learning. In J. P. Lantolf \& G. Appel (Eds.), Vygotskian approaches to second language research (pp. 33-56). Norwood, NJ: Ablex. https://doi.org/10.1111/j.1944-9720.1994.tb01214.x

Donato, R., \& Antonek, L. J. (1996). Monitoring and assessing a Japanese FLES program: Ambiance and achievement. Language Learning, 46, 497-528. https://doi.org/10.1111/j.1467-1770.1996.tb01245.x

Donato, R., Antonek, L. J., \& Tucker, R.G. (1994). A multiple perspective analysis of a Japanese FLES program. Foreign Language Annals, 27, 365-377. https://doi.org/10.1111/j.1944-9720.1994.tb01214.x

Fishbein, M. (1967). Attitude theory and measurement. New York: Wiley.

Fishbein, M., \& Ajzen, I. (1975). Belief, attitude, intention and behavior: An introduction to theory and research. Reading, MA: Addison: Wesley.

Fontecha, A. F., \& Gallego, M. T. (2012). The role of motivation and age in vocabulary knowledge. Vigo International Journal of Applied Linguistics, 9, 39-62.

Fox, D., \& Lorge, I. (1962). The relative quality of decisions written by individuals and by groups as the available time for problem solving is increased. Journal of Social Psychology, 57, 227-242. https://doi.org/10.1080/00224545.1962.9710920

Gardner, R. C., Lalonde, R. N., \& Moorcroft, R. (1985). The role of attitudes and motivation in second language learning: Correlational and experimental considerations. Language Learning, 35(2), 207-227. https://doi.org/10.1017/S0272263100009724

Gardner, R. C., \& MacIntyre, P. D. (1991). An instrumental motivation in language study: Who says it isn't effective? Studies in Second Language Acquisition, 26, 57-72. https://doi.org/10.1017/S0272263100009724

Glasser, W. (1986). Control theory in the classroom. New York: Harper.

Gomleksize, M. N. (2007). Effectiveness of cooperative learning (jigsaw II) method in teaching English as a foreign language to engineering students (case of Firat University, Turkey). European Journal of Engineering Education, 32(5), 613-625. https://doi.org/10.1080/03043790701433343

Green, J. M. (1993). Student attitude toward communicative and non-communicative activities: Do enjoyment and effectiveness go together? The Modern Language Journal, 77(1), 1-10. 
https://doi.org/10.1017/S0272263100009724

Greenop, K. (2007). Students' perceptions of efficacy and preference for two lecture formats. South African Journal of Psychology, 37(2), 361-367. https://doi.org/10.1177/008124630703700212

Ho, D. Y. F., Chan, F. S., \& Peng S. (2001). An investigative research in teaching and learning. In F. Salili \& S. Y. Chiu (Eds.), Multiple competencies and self-regulated learning: Implications for multicultural Education. Greenwich, CT: Information Age Publishing.

Hu, M., \& Nation, I. S. P. (2000). Vocabulary density and reading comprehension. Reading in a Foreign Language, 23(1), 403-430.

Huang, C. C. (2001). An investigation of ESP students' vocabulary knowledge and reading comprehension (pp. 435-445). Selected Papers from the Tenth International Symposium on English Teaching. Taipei, Taiwan: Crane.

Hui, L. (2005). Chinese cultural schema of education: Implications for communication between Chinese students and Australian educators. Issues in Educational Research, 15(1), 17-36.

Ibnian, S. S. K. (2012). Group work and attitudes of non-English major students towards Learning EFL. International Journal of Humanities and Social Science, 2(4), 192-197.

Johnson, D. W., \& Johnson, R. T. (1994). Learning together and alone. London: Allyn and Bacon.

Kowal, M., \& Swain, M. (2010). Using collaborative language production tasks to promote students' language awareness. Language Awareness, 3(2), 73-93. https://doi.org/10.1080/09658416.1994.9959845

Krashen, S. D. (1988). Second language acquisition and second language learning. Prentice-Hall International.

Krashen, S. D. (2011). Free voluntary reading. US: Libraries Unlimited.

Laufer, B. (1989). What percentage of text-lexis is essential for comprehension? In C. Lauren \& M. Nordman (Eds.), Special language: From humans to thinking machines (pp. 316-323). Clevedon: Multilingual Matters.

Laufer, B. (1992). Reading in a foreign language: How does L2 lexical knowledge interact with the reader's general academic ability? Journal of Research in Reading, 15, 95-103. https://doi.org/10.1111/j.1467-9817.1992.tb00025.x

Laufer, B., \& Ravenhorst-Kalovski, G. C. (2010). Lexical threshold revisited: Lexical text coverage, learners' vocabulary size and reading comprehension. Reading in a Foreign Lanugage, 22(1), 15-30. Retrieved Auguse 05, 2014, from http://files.eric.ed.gov/fulltext/EJ887873.pdf

Li, K. Y. (2011). Effects of cooperative learning on learning motivation and reading comprehension of EFL college students. Unpublished M.A. dissertation, National Yunlin University of Science \& Technology, Taiwan.

Li, L. Y., \& Vandermensbrugghe, J. (2011). Supporting the thesis writing process of international research students through an on-going writing group. Innovations in Education and Teaching International, 48(2), 195-205. https://doi.org/10.1080/14703297.2011.564014

Littlewood W. (2001). Students' attitudes to classroom English learning: A cross-cultural study. Language Teaching Research, 5(1), 3-28. https://doi.org/10.1177/136216880100500102

Lin, C. C., Chan, H. J., \& Hsiao, H. S. (2011). EFL students' perceptions of learning vocabulary in a computer-supported collaborative environment. ERIC Document Reproduction Service No. EJ 932229.

Lin, S. F. (2009). Teachers' use of and attitude towards vocabulary learning through group work by university students in Taiwan. Unpublished M.A. dissertation, Language \& Linguistics Department, University of Essex.

Lin, S. F. (2013). The effectiveness of and students' attitude toward learning English vocabulary through group work versus individual work in a Taiwanese university. Unpublished $\mathrm{PhD}$. theses, Language \& Linguistics Department, University of Essex.

Lin, S. F. (2018). The effect of group work on English vocabulary learning. Journal of Education and Learning, 7(4), 163-178. https://doi.org/10.5539/jel.v7n4p163

Lo, P. Z. (2012). Effects of using socialnetworking on college students' English writing skills in the process of cooperative learning. Unpublished M.A. dissertation, Asia University. 
MacIntyre, P. D., \& Gardner, R. C. (1989). Anxiety and second language learning: Toward a theoretical clarification. Language Learning, 32, 251-275. https://doi.org/10.1111/j.1467-1770.1989.tb00423.x

MacIntyre, P. D., \& Gardner, R. C. (1994). The effects of induced anxiety on three stages of cognitive processing in computerized vocabulary learning. Studies in Second Language Acquisition, 16, 1-17. https://doi.org/10.1017/S0272263100012560

McDonough, K. (2004). Learner-learner interaction during pair and small group activities in a Thia EFL context. System, 32, 207-224. https://doi.org/10.1016/j.system.2004.01.003

Nation, I. S. P. (2013). Learning vocabulary in another language. Cambridge: Cambridge University Press. https://doi.org/10.1017/CBO9781139858656

Noels. (2001a). Learning Spanish as a second language: learners' orientations and perceptions of their teachers' communication style. Language Learning, 51, 107-144. https://doi.org/10.1111/0023-8333.00149

Noels, K. A., Clément, R., \& Pelletier, L. G. (1999). Perceptions of teachers' communicative style and students' intrinsic and extrinsic motivation. Modern Language Journal, 83, 23-34. https://doi.org/10.1111/0026-7902.00003

Ohta, A. S. (2000). Rethinking interaction in SLA: Developmentally appropriate assistance in the zone of proximal development and the acquisition of L2 grammar. In J. P. Lantolf (Ed.), Sociocultural theory and second language learning (pp. 51-78). Oxford University Press.

Ohta, A. S. (2001). Peer interactive tasks and assisted performance in classroom language learning. In A. S. Ohta (Ed.), Second language acquisition processes in the classroom: Learning Japanese (pp. 73-128). Mahwah, NJ: Lawrence Erlbaum. https://doi.org/10.4324/9781410604712

Patton, M. Q. (2002). Qualitative research and evaluation methods (3rd ed.). California: SAGE Publications, Inc.

Rasinger, S. (2008). Quantitative research in linguistics. London: Continuum.

Roediger, H. L., \& Butler, A. C. (2011). The critical role of retrieval practice in long-term retention. Trends in Cognitive Science, 15(1), 20-27. https://doi.org/10.1016/j.tics.2010.09.003

Rupley, W. H., Long, J. W., \& Nichols, W. D. (1999). Vocabulary instruction in a balanced reading program. Reading Teacher, 52(4), 336-346.

Schmitt, N., Jiang, X., \& Grabe, W. (2011). The percentage of words known in a text and reading comprehension. The Modern Language Journal, 95(1), 26-43. https://doi.org/10.1111/j.1540-4781.2011.01146.x

Soureshjani, K. H., \& Naseri, N. (2011). The interrelationship of instrumental, integrative, intrinsic, and extrinsic motivations and the lexical-oriented knowledge among Persian EFL language learners. Theory and Practice in Language Studies, 1(6), 662-679. https://doi.org/10.4304/tpls.1.6.662-670

Storch. (2005). Collaborative writing: Product, process, and students' reflection. Journal of Second Language Writing, 14, 153-173. https://doi.org/10.1016/j.jslw.2005.05.002

Swain, M., \& Lapkin, S. (1998). Interaction and second language learning: Two adolescent French immersion students working together. The Modern Language Journal, 82, 320-337. https://doi.org/10.1111/j.1540-4781.1998.tb01209.x

Taqi, H. A., \& Al-Nouh, N. A. (2014). Effect of group work on EFL students' attitudes and learning in higher education. Journal of Education and Learning, 3(2), 52-65. https://doi.org/10.5539/jel.v3n2p52

Tseng, W. T., \& Schmitt, N. (2008). Toward a model of motivated vocabulary learning: A structural equation modeling approach. Language Learning, 58(2), 357-400. https://doi.org/10.1111/j.1467-9922.2008.00444.x

Tuan, T. A., \& Neomy, S. (2007). Investigating group planning in preparation for oral presentations in an EFL class in Vietnam. Regional Language Centre Journal, 38(1), 104-124. https://doi.org/10.1177/0033688206076162

Vygotsky, L. (1978). Interaction between learning and development. Mind in Society. Cambridge, MA: Harvard University Press.

Watanabe, Y. (2008). Peer-peer interaction between L2 learners of different proficiency levels: Their interactions and reflections. The Canadian Modern Language Review, 64(4), 605-635. https://doi.org/10.3138/cmlr.64.4.605 
Wichadee, S. (2007). The effect of cooperative learning on English reading skills and attitudes of the first-year students at Bangkok University. Retrieved September 4, 2015, from https://www.bu.ac.th/knowledgecenter/epaper/july_dec2005/saovapa.pdf

Zhang, Y. (2015). Chinese students' perceptions of cooperative learning in Finland. Master's in Education dissertation. Finland: Faculty of Education of University of Jyväskylä.

Zheng, Y. (2012). Exploring long-term productive vocabulary development in an EFL context: The role of motivation. System, 40, 104-119. https://doi.org/10.1016/j.system.2012.01.007

\section{Appendix A}

\section{Vocabulary exercise for text 1}

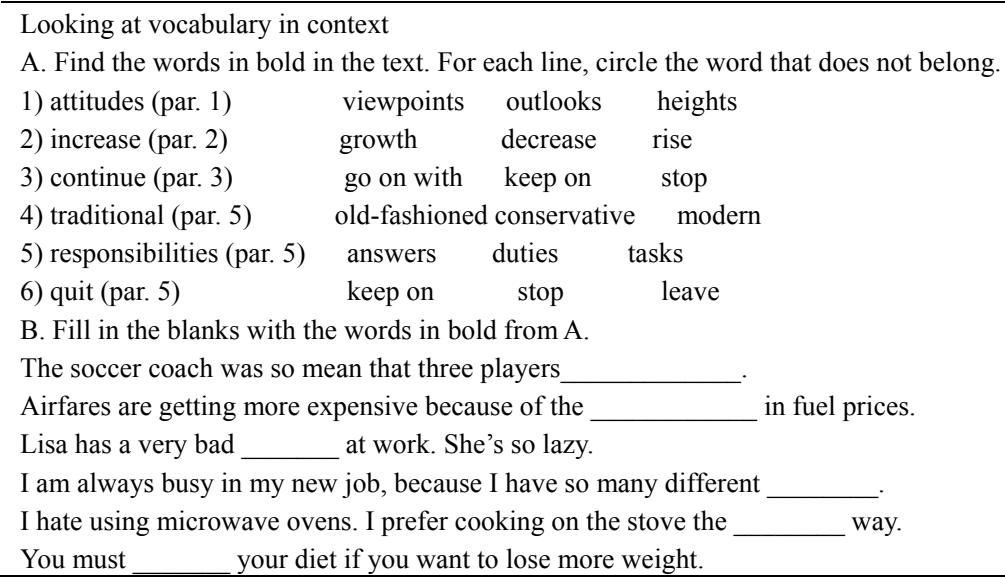

In part $\mathrm{A}$, the form, meaning, synonyms, antonyms, and occasionally spelling of the target words were practised. In part B, the meaning of the target words and part of speech were practised through the exercise. Part B also showed examples of collocation that were different from the original text.

\section{Vocabulary exercise for text 2}

Looking at vocabulary in context

A. Find the words in bold in the text. Circle the correct definitions.

1) Experts (par. 2) are people with special knowledge or skills/who are not paid for their work.

2) If you sleep for an average (par. 3) of six hours a night, you sleep for exactly six hours every night / more on some nights and less other nights.

3) Deprivation (par. 4) means having enough of something/not having enough of something.

4) Symptoms (par. 4) of an illness are the signs/causes of the illness.

5) A debt (par. 5) is something you must pay back/a special advantage.

6) Disorders (par. 6) are illness/accidents.

B. Fill in the blanks with the words in bold from A. Be sure to use the correct forms.

1) Sandy took out many loans for medical school, so it will take him a long time to pay off his

2) I want the advice of an ___ so I hired the best lawyer in town.

3) The _t_ temperature in San Francisco during the summer is 17 degrees.

4) That medical practice takes care of people with eating

5) Food__ is a big problem in many African countries.

6) Common_ of 'flu include fever, sore throat and pain.

The first vocabulary exercise for text 2 practised the meaning of target words in relation to synonyms and antonyms in paraphrases. The second exercise for text 2 was similar to that for text 1. 


\section{Appendix B}

\section{Pre-questionnaire}

"The effectiveness of and students' attitude towards learning vocabulary through group work in university in Taiwan"

Dear students:

This survey is conducted by PhD student Lin Su-Fei from the Language and Linguistics Department of the University of Essex. This questionnaire is to understand "The effectiveness of and students' attitude towards learning vocabulary through group work and individual work in university in Taiwan". Your personal opinion and sincere responses are considered valuable to my study. All the answers in the questionnaire will be kept confidential and only be used for my research. Thank you very much for your assistance and cooperation.

University of Essex

Department of Language and Linguistics

Researcher Lin Su-Fei

Name:

Student ID No.:

Part A: Personal Information

Please tick

1) Sex: Male ( ) Female ()

2) Age: $18-20$ () 21-23 () 24-26 () 27-29 () 30-32 ()

3) How long have you been learning English?

4) Besides learning English at school, have you ever learnt English in other places?

Yes ( ) [Please go to 5,6] No ( ) [Please go to 7]

5) Where do you learn English? (Tick as many as apply)

Cram school () After-school club () Study abroad () Others () (Please say)

6) How long have you learnt English there?

Cram school

After-school club

Study abroad

Others (Please say)

7) Have you ever participated in group work activities (the class is split into groups of 3 students and all the groups work at the same time on the same task) in the English classes?

Yes ( ) [Please go to 8] No ( ) [Please go to 9]

8) Where is it?

Elementary school () Junior high school () Senior high school ()

University ( ) Others_____ (Please say)

9) What year are you in university study?

First year () Second year ( ) Third year () Fourth year ()

10) What is your major?

Multimedia design ( ) Biotechnology ( ) electronic engineering ( ) electro-optical engineering ( )

Part B:

"What is your attitude about working on vocabulary task individually or working in group of 3 in the English class?"

Please tick ${ }^{\circ}$

1) How much do you think you would like learning English vocabulary by working on tasks individually in class?

$\begin{array}{ccccc}\text { A lot ( ) } & \text { Moderately ( ) } & \text { Somewhat ( ) } & \text { Little ( ) } & \text { Not at All ( ) } \\ 4 & 3 & 2 & 1 & 0\end{array}$


2) How successfully do you think you would learn English vocabulary by working on tasks individually in class?

$\begin{array}{ccccc}\text { A lot () } & \text { Moderately () } & \text { Somewhat () } & \text { Little ( ) } & \text { Not at All () } \\ 4 & 3 & 2 & 1 & 0\end{array}$

3) How well do you think you would concentrate on the English vocabulary tasks when working individually in class?

$\begin{array}{ccccc}\text { A lot () } & \text { Moderately ( ) } & \text { Somewhat () } & \text { Little ( ) } & \text { Not at All ( ) } \\ 4 & 3 & 2 & 1 & 0\end{array}$

4) How confident do you think you would feel by working individually on vocabulary task in class?
A lot (
Moderately ( )
Somewhat ( )
Little ( )
Not at All ( )
4
3
2
1
0

5) How motivated do you think you would be by working individually on vocabulary task in class?

$\begin{array}{ccccc}\text { A lot () } & \text { Moderately () } & \text { Somewhat () } & \text { Little () } & \text { Not at All () } \\ 4 & 3 & 2 & 1 & 0\end{array}$

6) How well supported do you think you would be when working individually on English vocabulary tasks in class?

$\begin{array}{ccccc}\text { A lot () } & \text { Moderately ( ) } & \text { Somewhat () } & \text { Little ( ) } & \text { Not at All () } \\ 4 & 3 & 2 & 1 & 0\end{array}$

7) How much stress do you think you would have from working individually on English vocabulary tasks in class?

$\begin{array}{ccccc}\text { A lot () } & \text { Moderately ( ) } & \text { Somewhat ( ) } & \text { Little ( ) } & \text { Not at All () } \\ 4 & 3 & 2 & 1 & 0\end{array}$

8) How efficiently do you think you would work on English vocabulary task individually in class?
A lot ()
Moderately ( )
Somewhat ( )
Little ( )
Not at All ( )

4

3

2

1

0

9) How much correct English vocabulary information do you think you would obtain by working individually in class?

$\begin{array}{ccccc}\text { A lot () } & \text { Moderately ( ) } & \text { Somewhat () } & \text { Little () } & \text { Not at All () } \\ 4 & 3 & 2 & 1 & 0\end{array}$

10) How much do you think you would like learning English vocabulary by working on tasks in group of 3 in class?
A lot ( )
Moderately ( )
Somewhat ( )
Little ( )
Not at All ( )
4
3
2
1
0

11) How successfully do you think you would learn English vocabulary by working on tasks in group of 3 in class?

$\begin{array}{ccccc}\text { A lot () } & \text { Moderately ( ) } & \text { Somewhat () } & \text { Little () } & \text { Not at All ( ) } \\ 4 & 3 & 2 & 1 & 0\end{array}$

12) How well do you think you would concentrate on the English vocabulary tasks by working in group of 3 in class?
A lot ( )
Moderately ( )
Somewhat ( )
Little ( )
Not at All ( )
4
3
2
1
0

13) How confident you think you would feel when working on English vocabulary task in group of 3 in class?
A lot (
Moderately ()
Somewhat ()
Little ( )
Not at All ( )
4
3
2
1
0 
14) How motivated do you think you would be by working on English vocabulary task in group of 3 in class?

$\begin{array}{lcccc}\text { A lot () } & \text { Moderately ( ) } & \text { Somewhat ( ) } & \text { Little ( ) } & \text { Not at All ( ) } \\ 4 & 3 & 2 & 1 & 0\end{array}$

15) How well supported do you think you would be when working on English vocabulary tasks in a group of 3 in class?

$\begin{array}{ccccc}\text { A lot () } & \text { Moderately ( ) } & \text { Somewhat () } & \text { Little () } & \text { Not at All () } \\ 4 & 3 & 2 & 1 & 0\end{array}$

16) How much stress do you think you would have from working on English vocabulary tasks in group of 3 in class?

$\begin{array}{ccccc}\text { A lot () } & \text { Moderately ( ) } & \text { Somewhat ( ) } & \text { Little ( ) } & \text { Not at All () } \\ 4 & 3 & 2 & 1 & 0\end{array}$

17) How efficiently do you think you would work on English vocabulary task in group of 3 in class?

$\begin{array}{ccccc}\text { A lot () } & \text { Moderately () } & \text { Somewhat () } & \text { Little () } & \text { Not at All () } \\ 4 & 3 & 2 & 1 & 0\end{array}$

18) How much correct English vocabulary information do you think you would obtain by working in a group of 3 in class?

$\begin{array}{ccccc}\text { A lot () } & \text { Moderately ( ) } & \text { Somewhat () } & \text { Little () } & \text { Not at All () } \\ 4 & 3 & 2 & 1 & 0\end{array}$

\section{Appendix C}

\section{Post-questionnaire}

"The effectiveness of and students' attitude towards learning vocabulary through group work in university in Taiwan"

Dear students:

This survey is conducted by PhD student Lin Su-Fei from the Language and Linguistics Department of the University of Essex. This questionnaire is to understand "The effectiveness of and students' attitude towards learning vocabulary through group and individual work in university in Taiwan". Your personal opinion and sincere responses are considered valuable to my study. All the answers in the questionnaire will be kept confidential and only be used for my research. Thank you very much for your assistance and cooperation.

\section{University of Essex}

Department of Language and Linguistics

\section{Researcher Lin Su-Fei}

Name:

Student ID No.:

Part A:

"What is your attitude about working on task individually or working in group of 3 in the English class?"

Please tick ${ }^{2}$

1) How much did you like learning English vocabulary by working on tasks individually in class?

$\begin{array}{ccccc}\text { A lot () } & \text { Moderately ( ) } & \text { Somewhat () } & \text { Little ( ) } & \text { Not at All ( ) } \\ 4 & 3 & 2 & 1 & 0\end{array}$

2) How successfully did you think you learnt English vocabulary by working on tasks individually in class?
A lot ( )
Moderately ( )
Somewhat ( )
Little ( )
Not at All ( )
4
3
2
1
0 
3) How well were you able to concentrate on English vocabulary tasks when working individually in class?

$\begin{array}{ccccc}\text { A lot () } & \text { Moderately () } & \text { Somewhat () } & \text { Little () } & \text { Not at All () } \\ 4 & 3 & 2 & 1 & 0\end{array}$

4) How confident did you feel by working individually in class?

$\begin{array}{ccccc}\text { A lot () } & \text { Moderately () } & \text { Somewhat () } & \text { Little () } & \text { Not at All () } \\ 4 & 3 & 2 & 1 & 0\end{array}$

5) How much motivation did you have when working individually on English vocabulary tasks in class?
A lot (
Moderately ( )
Somewhat ( )
Little ( )
Not at All ( )
0

4

3

2

1

6) How much support did you have when working individually on English vocabulary tasks in class?
A lot (
Moderately ( )
Somewhat ( )
Little ( )
Not at All ( )

$\begin{array}{lllll}4 & 3 & 2 & 1 & 0\end{array}$

7) How much stress did you have when working on English vocabulary tasks individually in class?
A lot ()
Moderately ( )
Somewhat ( )
Little ( )
Not at All ( )

$4 \quad 3$

2

1

0

8) How efficient did you think you worked on English vocabulary task individually in class?
A lot ()
Moderately ( )
Somewhat ( )
Little ( )
Not at All ( )
4
3
2
1
0

9) How much correct vocabulary information did you obtain by working on English vocabulary individually in class?

$\begin{array}{ccccc}\text { A lot () } & \text { Moderately () } & \text { Somewhat () } & \text { Little () } & \text { Not at All () } \\ 4 & 3 & 2 & 1 & 0\end{array}$

10) How much did you like learning vocabulary by working on tasks in a group of 3 in class?
A lot ( )
Moderately ( )
Somewhat ( )
Little ( )
Not at All ( )
$4 \quad 3$
2
1
0

11) How successfully did you think you learn English vocabulary by working on tasks in a group of 3 in class?
A lot (
Moderately ( )
Somewhat ( )
Little ( )
Not at All ( )
43
2
1
0

12) How well were you able to concentrate on English vocabulary tasks by working in a group of 3 in class?
A lot ( )
Moder
Little ( )
Not at All ( )

4

32

13) How confident did you feel when working on English vocabulary tasks in a group of 3 in class?

$\begin{array}{ccccc}\text { A lot () } & \text { Moderately () } & \text { Somewhat () } & \text { Little () } & \text { Not at All () } \\ 4 & 3 & 2 & 1 & 0\end{array}$

14) How much motivation did you have when working on English vocabulary tasks in a group of 3 in class?

$\begin{array}{lcccc}\text { A lot () } & \text { Moderately ( ) } & \text { Somewhat ( ) } & \text { Little ( ) } & \text { Not at All ( ) } \\ 4 & 3 & 2 & 1 & 0\end{array}$

15) How much support did you have when working on English vocabulary tasks in a group of 3 in class?
A lot ( )
Moderately ( )
Somewhat ( )
Little ( )
Not at All ( )
4

$$
3
$$
2
1
0

16) How much stress did you have when working on English vocabulary tasks in a group of 3 in class?
A lot ( )
Moderately ( )
Somewhat ( )
Little ( )
Not at All ( )
4
3
2
1
0 
17) How efficiently did you think you worked on English vocabulary tasks in a group of 3 in class? A $\operatorname{lot}($
Moderately ( )
Somewhat ( )
Little ( )
Not at All ( )
4
3
2
1
0

18) How much correct English vocabulary information did you obtain when working in a group of 3 in class?

$\begin{array}{ccccc}\text { A lot ( ) } & \text { Moderately ( ) } & \text { Somewhat ( ) } & \text { Little () } & \text { Not at All () } \\ 4 & 3 & 2 & 1 & 0\end{array}$

\section{Copyrights}

Copyright for this article is retained by the author, with first publication rights granted to the journal.

This is an open-access article distributed under the terms and conditions of the Creative Commons Attribution license (http://creativecommons.org/licenses/by/4.0/). 